\title{
The Child Labor Problem and the Need for International Labor Standards
}

Thomas I. Palley

\section{Child Labor as a Problem of Labor Markets and Economic Development}

The problem of exploitative child labor has received much attention in recent years. According to the International Labor Organization (ILO) there are approximately 250 million working children aged between five and fourteen, of which at least 120 million are involved in full-time work that is both hazardous and exploitative. Such labor is spread throughout the developing world. Measured in absolute terms, Asia has the highest incidence of child labor (152.5 million), followed by Africa ( 80 million) and Latin America (17.5 million). Measured in proportional terms approximately 40 percent of African children work, while 20 percent of children work in Asia and Latin America respectively. ${ }^{1}$

Driven by public outrage in developed countries, the issue of exploitative child labor has received increasing attention. Yet solutions remain elusive, and they are made more complicated by the fact that the extent of child labor reflects a country's level of economic development. This means that developed country calls for prohibition can seem hollow in the eyes of developing countries, which maintain that the developed countries themselves relied extensively on child labor when they were at a similar stage of economic development.

Given this contentious environment there has been a tendency to promote policies of unofficial voluntarism whereby private producers adopt codes of practice that bar the use of child labor. These voluntaristic practices are exemplified by private labeling

The author is Director of the Globalization Reform Project with the Open Society Institute. This paper was presented at a conference on child labor at the Graduate School of Social Work, University of Utah, Salt Lake City, May 7-8, 2001. The author thanks the journal editor and an anonymous referee for helpful comments connecting the argument in the paper to the earlier work of Progressive Era institutional economists. 
schemes, such as Rugmark in the carpet industry, which certify to consumers that a product has been produced without child labor.

Such labeling policies focus exclusively on child labor and implicitly treat it as a stand-alone problem that can be addressed by independent stand-alone policies. This paper argues for a profound reformulation of the child labor problem whereby it is viewed as a labor market and economic development problem. Child labor is intimately connected to the operation of labor markets, and solving the former therefore depends on solving problems that afflict developing country labor markets. Child labor is also connected to economic development, and addressing the child labor problem therefore also requires policies that foster development. Labor market dysfunction and under-development are the root causes of exploitative child labor. Viewed in this light, the ILO's core labor standards become a critical instrument for solving the child labor problem because they tackle both of these root causes.

Finally, there remains a place for voluntaristic codes of conduct, but it must also be recognized that such codes cannot address the underlying roots of the problem. More sunshine is always better than less, and voluntaristic codes can serve an extremely valuable function in galvanizing public opinion to move against child labor and labor market exploitation. However, it is important that codes not be presented as a substitute for official core labor standards. ${ }^{2}$ If this happens, voluntaristic codes will make a negative contribution by fracturing understandings and diverting support away from core labor standards.

\section{Labor Standards and the Link to Institutional Economics of the Progressive Era}

Before turning to specific analysis of the problem of child labor and its relation to labor standards, it is worth noting how today's debate over labor standards has clear links with the early twentieth century Progressive Era-thinking of American institutional economists. One notable link is with John Commons' (1909) theoretical concept of "competitive menace." Commons developed the notion of competitive menace in his history of American shoemaking, describing it as operating through the marginal producer who is used to bid down standards and wages throughout an industry.

Defining the "marginal producer" as the one with the lowest standards of living and cost and quality of work, he is the producer whose competition tends to drag down the level of others toward his own. It is not necessary that he be able to actually supply the entire market or even the greater part of it. His effect on others depends on the extent to which he can be used as a club to intimidate others against standing out for their side of the bargain. He is a menace rather than an actual competitor. Now the extension of the market for the sale of goods is accompanied by an extension of the field for production of goods. This extension brings into competitive area new competitors who are essentially a series of lower marginal producers.... Thus the extension of the field of pro- 
duction increases the variety and discovers the lower levels of marginal producers, and the merchant-capitalist emerges as the generalissimo, menacing in turn every part of the field from his strategic center. (Commons 1909, 68-69)

Glen Atkinson (1997) has emphasized the relevance of Commons' competitive menace framework for understanding today's process of globalization, and the parallels are clear. Globalization has extended the field for production of goods, which has resulted in entry at the margin of new low-standard producers. Though these marginal producers are unable to supply the entire market, the threat of production shifting is sufficiently credible that their entry can be leveraged to lower standards everywhere. And at the center of the process remains the merchant-capitalist generalissimo, who in today's global economy is the multinational corporation which sub-contracts globally and then retails this production in developed country consumer markets. The "race to the bottom," which is discussed later in the paper in terms of the prisoner's dilemma, partakes of a game-theoretic dynamic that is strikingly similar to Commons' competitive menace. And competitive menace is also germane to the problem of child labor, which is increasingly entwined with the globalization of production.

Seen in this light, solving the problem of competitive menace, as it operates in the global economy, requires new institutions that promote a different path of development. Atkinson (1997) termed these institutions "rules governing bargaining transactions," and labor standards are just this. By blocking off the low road development path associated with the race to the bottom, labor standards compel business to shift to an alternative high development path that is more inclusive and deeper owing to its reliance on growth of domestic markets. This rules approach echoes the Progressive Era approach to market economies outlined by Leo Wolman of the New School:

Rules of the game prevail in business and industry as they do in sport; and in both the rules serve much the same purpose. They prevent confusion by supplying the players with an orderly procedure; or they assure the participants in the game that fair and equal treatment; or they provide standards of performance that establish the levels on which the games are played. Long experience with the lighter as well as the more serious activities of life has taught us that players can not always be trusted to make their own rules or, when they make them, to enforce them. $(1924,226)$

A second link is with Progressive Era economists' discussion of the minimum wage. Robert Prasch $(1998,1999)$ provided a thoughtful survey of the arguments raised by these economists, and many have clear parallels with today's arguments for global labor standards. ${ }^{3}$ This points to the lasting vitality and relevance of institutionalism as a frame for understanding the economy.

In making the case for a national minimum wage, Progressive Era economists emphasized the issue of bargaining power, and this, too, figures prominently in the case for labor standards. Interestingly, the bargaining power argument was raised by both 
institutionalists and neoclassicists. Thus, John Bates Clark, the originator of marginal product theory of income distribution, wrote:

Hunger-discipline disqualifies the worker for making a successful bargain, and if the employer were everywhere at liberty to take men for what, under such pressure, they might individually offer to work for, he might get them for very little. $(1913,292)$

Another Progressive Era argument for a minimum wage was that of parasitic industries, whereby sweated industries paid less than that needed for subsistence, thereby forcing the cost of social reproduction on to others. This imposes an external cost on others.

The real injury becomes diffused, not revealing its harmful effects except indirectly and after the lapse of time. This injury is none the less real. The industry is parasitic. Society is not entitled to the products of an industry that is not self-supporting on the basis of the human "live and let live" principle. Not until an industry has developed the ingenuity, the inventive and organizing ability, to make it self-sustaining in all of its returns, ought society to have that industry. (Groat 1913, 109)

This parasitic industry argument has similarities with "race to the bottom" arguments for labor standards. The difference is that the parasitic industry argument is constructed in terms of a static externality, whereas "race to the bottom" arguments rest on a dynamic externality with standards compelling a high road development path in place of a low road one. Yet, even here Progressive Era economists anticipated elements of the contemporary debate. Thus, Florence Kelley of the National Consumer's League of New York wrote:

The universally observed tendency is, however, that every improved standard of hours, wages, or conditions forced upon an industry for the good of the employees tends not to increase the retail price of the product, but to enhance the efficiency of management. Improved apparatus already upon the market, but not installed for the reason of cost of installation, tends to be promptly installed when working-hours are shortened, or the age of the working child raised by statute, or the wage scale of home-workers fixed by an outside body. (1912, 1008)

M. Altman (2001) made some similar arguments in connection with child labor, maintaining that banning child labor need have no negative impact on costs if it results in the substitution of efficient adult labor in place of less efficient child labor.

Whereas it is possible to find close similarities between a core labor standards-development approach to child labor and the minimum wage arguments of Progressive Era institutional economists, the same cannot be said for the modern neoclassical approach to child labor. Thus, K. Basu and P. H. Van (1998) portrayed the problem of child labor as one of multiple equilibrium. In their model the presence of 
child labor represents a case in which the bad equilibrium prevails. From their perspective all that is needed is to enforce a ban on child labor, thereby making the good equilibrium without child labor the only sustainable equilibrium. C. Grootaert and R. Kanbur (1995) adopted a more mixed stance. On one hand they recognized that child labor is a problem of under-development. However, instead of identifying the problem as one of institutional malfunctioning of labor markets that can only be remedied by enforcement of core labor standards, they suggested neoclassical-styled incentive policies aimed at twisting relative returns to families in a fashion that makes school more attractive than child labor. Such adjustments can undoubtedly help at the margin, but they are unlikely to be sufficient if the root cause of child labor is lack of jobs paying an adequate wage.

\section{ILO Core Labor Standards: What Are They?}

The ILO's core labor standards consist of five articles. ${ }^{4}$ Three are prohibitive in character, banning forced labor, exploitative child labor, and discrimination. Two are affirmative in character, affirming workers the right of freedom of association and the right to engage in collective bargaining. These five core labor standards are elaborated in the ILO's Declaration of Fundamental Principles and Rights at Work, which was adopted in 1998. The five core labor standards, with reference to the fundamental ILO Conventions that give them content, are described below:

1. Freedom of Association-The ILO Freedom of Association and Protection of the Right to Organize Convention (No. 87) establishes the right of workers to form and join organizations, including unions, of their own choosing. Governments may not dictate the form, affiliations, or internal operations of such organizations and may not deny authorization to nor suspend such organizations.

2. Effective Recognition of the Right to Collective Bargaining-The Right to Organize and Collective Bargaining Convention (No. 98) protects unions from outside interference. Employers may not discriminate against workers who join organizations of their own choosing, nor may they pay for and establish their own workers' organizations. The state must establish legal mechanisms to prevent this interference. The government must also promote voluntary collective bargaining between workers' organizations and their employers.

3. The Elimination of All Forms of Forced or Compulsory Labor-The Forced Labor Convention (No. 29) and the Abolition of Forced Labor Convention (No. 105) require governments to suppress all forms of forced and compulsory labor in their territories. Forced labor is any form of labor which a worker performs under threat of penalty rather than voluntarily. Though there are very limited 
exceptions for the military and national emergencies, government prohibitions on forced labor must be comprehensive.

4. The Effective Abolition of Child Labor-The Minimum Age Convention (No. 138) sets a baseline minimum working age of fifteen. If a country is insufficiently developed, or if only light work is involved, the minimum age can be lower; conversely, for hazardous occupations the minimum age is eighteen. States must adopt and pursue national policies that effectively end child labor and allow children to fully develop both physically and mentally.

5. The Elimination of Discrimination in Respect of Employment and Occupation-The Discrimination Convention (No. 111) requires governments to establish national policies that eliminate discrimination on the basis of race, color, sex, religion, political opinion, and national or social origin. Discrimination includes unequal access to employment and training as well as disparate working conditions, and the national policy must address both unequal opportunities and treatment. The Equal Remuneration Convention (No. 100) completes this standard by establishing the right of men and women to equal pay for work of equal value.

A particularly important feature is that they are "qualitative" in nature and not "quantitative." Unfortunately, all too often they are misrepresented as quantitative measures that set minimum wage levels or maximum hours of work, both of which are labor market interventions that are clearly contingent on the stage of development. This qualitative character of core labor standards reflects a recognition that some standards are universal and apply regardless of a country's stage of development.

\section{The Case for Labor Standards}

The case for labor standards can be argued in a number of ways. This section briefly visits the "human rights" and "parity" cases for labor standards and then turns to examine the "economic" case in detail. This attention to the economic case for labor standards reflects the fact that economic arguments are increasingly decisive in the making of policy today.

The first justification for labor standards rests on a human rights argument. Such an argument might be constructed on the grounds that work is a central activity of life, and as such plays a key role in the creation of self-identity, in personal development, and the achievement of personal fulfillment. Consequently, human beings should have some core rights at work to ensure that work contributes positively to these aspects of human growth.

A second justification that has much popular appeal is the parity argument. Here, the reasoning is that over the last several years various international trade agreements have conferred many global rights on investors and their intellectual property (IP), and 
consequently working people should also be given equivalent global rights and legal protections. Though having much popular political traction there are reasons for caution here. In particular, there are strong grounds for believing that existing investor and IP rights are wrong and unjustified. Lawyers love to talk of "intellectual property" because this makes any change in the law appear to be a form of "confiscation." However, the reality is that IP is a metaphor for a set of socially constructed constantly changing rules, and ranged against IP rights are a set of equally important values such as the right of people to imitate others, to work, talk, and write freely, and to nurture common cultures. Given this, there is a danger that the parity argument may link labor standards with unjustifiable IP rights that need to be repealed.

In contrast to the parity argument, the economic argument for labor standards makes an affirmative self-standing case for labor standards. This economic argument recognizes the labor market and economic development roots of the child labor problem. Addressing these roots leads to a focus on core labor standards, especially those concerned with the rights of freedom of association and collective bargaining. This is because these rights are key to success regarding child labor, discrimination, and forced labor. Given this, core labor standards should be made a central element of the system of global governance that is now being constructed, and all countries should be pushed to conform to these standards. Unfortunately, labor standards are frequently accused of being a form of "hidden protection" that gives unfair protection to industrialized country workers by taking away comparative advantage of workers in developing countries. As is argued below, this claim is fundamentally wrong. Labor standards are good for both developing and developed countries, and exemplify how good economic policy can promote win-win outcomes.

\section{Lessons from the Past}

Before turning to abstract economic arguments it is worth briefly reflecting on the development history of the United States, which provides a concrete example of why there is a need for the type of rights embodied in core labor standards. In the nineteenth and early twentieth century the USA was marked by formation of an integrated national economy. This process was driven by the steamboat, the railroad, and the automobile, which integrated the component regional economies, and it was marked by many of same problems that are seen today in the global economy. Workplaces were unsafe, wages were low, and workers were subject to exploitation. All of these features were captured in books such as Upton Sinclair's The Jungle (1905). There was widening income and wealth inequality, and the national economy was prone to periodic booms and slumps, the most extreme example of which was the Great Depression.

Within the United States the response was to create rules and institutions that addressed these problems. Financial markets were tamed by the creation of the Federal Reserve System and the Securities Exchange Commission, while goods markets were stabilized by antitrust laws and the adoption of countercyclical monetary and fiscal poli- 
cies. In labor markets the solution was the implementation of national labor standards. The Wagner Act (1935) and National Labor Relations Act (1938) granted workers the right of freedom of association to form trade unions and bargain collectively. The Fair labor Standards Act (1940) established a national minimum wage and set the standard workweek at forty hours, and required overtime pay for work above this. Moreover, such legislation was developed on a federal basis explicitly to stop a race to the bottom among the states (Elmslie and Milberg, 1996). ${ }^{5}$

The result of this legislation was to improve workplace standards, encourage firms to enhance productivity by innovation rather than exploitation, and give working people the income to buy what they produce, thereby solving the problem of demand shortages that previously contributed to gluts and depressions. These measures also made for "deep" development based on robust mass consumption markets, for ultimately a mass production economy requires mass consumption markets. Improved wages also helped reduce wealth and income inequality, which in turn reduced political conflict. Finally, the growth of trade unions contributed to the development of a healthy democratic politics in which the existence of balanced countervailing forces was able to check monopolistic tendencies.

The bottom line is that no country has experienced successful democratic market development without giving workers the rights embodied in core labor standards, and this historical experience should inform today's debate about the place of labor standards in developing countries. National economic integration was the problem of yesteryear: global economic integration is the problem of today. Yet the two processes share a common underlying economic logic, and it is for this reason that the policy responses that worked to create prosperity earlier remain an instructive guide for today.

\section{Arguments for Today}

Analogies with the past can help illuminate labor market and development problems of today, but they must be accompanied by arguments rooted in the analytic specifics of today. In many regards the core labor standards prohibition of "exploitative" child labor is the most complicated of the five standards. This is because the child labor problem clearly has a stage-of-development dimension that makes discussion more complicated. It is a paradox that the child labor question has greatest public traction, and yet it is also the most complicated owing to its stage-of-development dimension.

That said, it is also clear that over any medium-term horizon the accumulation of human capital is key to economic development. This means that having children in school rather than earning a meager family income supplement is good development policy. Having rules that prompt developing countries to enhance education is therefore a good thing. However, for such rules to be successful three things are required. First, there is a need to invest in education to provide school buildings and train and pay schoolteachers. This involves government spending. If children are to be taken out of the workplace in the name of educating them, needed educational resources have to be 
funded. Second, work must pay wages that allow a family to subsist. Child labor exists because children earn vitally needed income for families. If society is going to stop children from working, then adult workers must be able to support their families. This is why core labor standards, as they pertain to freedom of association and collective bargaining, are so critical to solving the child labor problem. Third, if child labor is eliminated then there must be adequate numbers of jobs for adults so that they can earn the wages needed to replace child incomes. Once again, this is where labor standards have a role to play since they contribute to the building of a development dynamic that leads to deep economic development. In sum, these arguments illustrate how child labor is a problem that links with wider problems concerning labor markets and economic development, and solving the child labor problem therefore calls for policies that tackle these broader problems.

Prohibition of all forms of discrimination is another core labor standard, and here too there are implications for child labor. Discrimination is morally repugnant and it is also economically inefficient in that society fails to fully realize the economic potential of all it members. Ending discrimination should therefore be a goal of all. However, it also has child labor implications. First, to the extent that female adult workers are underpaid, it may make it harder for families to earn an adequate income and thereby may drive more children into the labor market. Second, some of the most exploitative forms of child labor-trafficking and sexual slavery-are concentrated among female children, and these practices are in turn connected to gender attitudes. Ending discrimination stands to empower women, and in doing so it can help reduce these especially abusive forms of child labor.

Eliminating discrimination, forced labor, and exploitative child labor are all ends. The rights to freedom of association and collective bargaining are both means and ends. Absent these rights, it is unlikely that prohibitions on discrimination and forced labor can be made effective in practice, nor will it be possible to create the labor market and economic development conditions necessary for the elimination of child labor. For these reasons, the rights to freedom of association and collective bargaining assume special importance. Yet, despite this, it is these rights that are frequently viewed with the greatest hostility by developing countries and labeled as "hidden protectionism."

Granting workers the legal rights of freedom of association and collective bargaining is good development policy. By promoting improved distribution of income such measures can foster development of robust domestic markets. This in turn allows wages to grow, giving rise to a virtuous circle in which rising wages support market development and market development supports rising wages. D. Rodrik (1999) provided evidence that democracies pay higher wages. Thomas Palley (1999) provided evidence that improved rights of free association correlate with faster growth in the five-year period after the improvements are made. Palley (2000) also provided evidence that income distribution is more equal in countries with better rights of freedom of association, as well as evidence that wages are higher in such countries. This finding potentially qualifies Rodrik's argument. Democracy still matters, but it matters because it creates the politi- 
cal conditions that allow for freedom of association, and freedom of association then becomes the actual instrument driving higher wages in labor markets.

Such arguments run completely counter to those advanced by the mainstream of the economics profession. According to the latter, unions are a "bad" in that they are a market distortion, nor does income distribution matter for economic development. However, a labor standards perspective rejects the view that unions are a market distortion. Instead, it argues that they are a private sector corrective to market failure-namely a huge imbalance of power between individual workers and business. Unions serve to create a level bargaining field. This in turn is good for development as it improves income distribution, thereby fostering domestic development rooted in the growth of domestic markets. Such growth contrasts with the "enclave" model of development as exemplified by export processing zones, which are the modern form of plantation development.

A second contribution of labor standards is that they promote good governance. There is now widespread recognition that good governance promotes successful development, and labor standards fit with this new view. Good governance, characterized by transparency and accountability, is necessary to prevent corruption and the misallocation of capital. Freedom of association and unions contribute to good governance by creating the countervailing power that can check such practices. Contrary to mainstream thinking, competitive markets alone cannot do this. Simply opening and liberalizing markets will not compete away the problem of corruption as market participants just get captured by corruption.

This is illustrated in figure 1, which constructs the problem of bribery in terms of the prisoner's dilemma. Each firm must make a decision to "bribe" or "not bribe." An equilibrium where neither firm bribes is socially optimal as neither firm wastes resources on bribing, and contracts are allocated on the basis of which firm is the most efficient. However, if one firm chooses not to bribe, then the other has a private incentive to bribe and secure the business. Consequently, both end up bribing, and the market left to itself is characterized by bribery. The only way to sustain the optimal "no bribery" equilibrium is to have political institutions that prevent bribery. Bribery and corruption are political problems, and their elimination requires political reform. Labor standards, through the right of freedom of association, can foster political conditions that promote such reforms. Palley (2000) reported evidence that countries with better rights of freedom of association have lower corruption, have greater economic security, and are more democratic.

Not only do labor standards promote conditions of good governance that facilitate domestic economic development, but there are also grounds for believing that labor standards can help resolve some of the contradictions that currently afflict the international economy. This accounts for the international win-win dimension of labor standards. In particular, the international economy is afflicted by the contradiction of export-led growth. The export-led growth paradigm embodies a "fallacy of composition" in that it leads all countries to aim for export surpluses. However, one country's exports 
Figure 1. The Problem of Bribery Represented in Terms of the Prisoner's Dilemma

\begin{tabular}{|ll|l|l|}
\hline \multicolumn{2}{c}{} & \multicolumn{2}{c}{ Firm A } \\
\cline { 3 - 4 } & \multirow{2}{*}{ Not bribe } & \multicolumn{1}{c|}{ Bribe } \\
\hline \multirow{2}{*}{ Firm B } & $\begin{array}{l}\text { A. } \\
\text { Anti- } \\
\text { bribery } \\
\text { convention }\end{array}$ & B. \\
\cline { 3 - 4 } & Bribe & C. & $\begin{array}{l}\text { D. } \\
\text { No anti- } \\
\text { bribery } \\
\text { convention }\end{array}$ \\
\hline
\end{tabular}

are another's imports, and this means that not all can run surpluses. What works for one cannot work for all. If all try to run surpluses and grow on the backs of their neighbors' markets, the result is a shortage of demand and global deflation.

For developing countries, a particular manifestation of the export-led problematic is ever-declining terms of trade. This is an old finding, first identified by Hans Singer and Raoul Prebisch in the 1950 s in connection with commodity prices. Now, owing to the persistent spread of export-led industrialization, developing countries may have entered a new era marked by secularly declining terms of trade for low end manufactured goods as well as commodities. In effect, developing countries may face the prospect of having to run to stay where they are. Moreover, this situation promises to increase financial instability since these countries must export ever more to pay their foreign debts, which then drives down prices further. The only long run solution is to have developing countries consume a greater portion of what they produce, thereby slowing the growth supply on international markets and driving up prices. However, for this to happen these countries need to fix their hugely unequal income distributions, and this is why labor standards are so crucial.

Another failing of the export-led growth model is that it is marked by an incentive structure that produces a race to the bottom. This is because each country has an incentive to try to gain international competitive advantage by exploiting every possible margin. Good competition focuses on productivity and quality: bad competition eats away at workplace safety, the environment, and income distribution. Labor standards can help by ruling out bad competition, and once again this can be understood in terms of the logic of the prisoner's dilemma as illustrated in figure 2. Each country has a choice whether to maintain or lower standards. The socially optimal equilibrium has both maintaining standards, but left to itself the market produces a socially sub-optimal outcome in which both lower standards. The logic is as follows. If one country maintains 
Figure 2. The Problem of Bribery Represented in Terms of the Prisoner's Dilemma

\begin{tabular}{|c|c|c|c|}
\hline & & \multicolumn{2}{|c|}{ Country A } \\
\hline & & $\begin{array}{l}\text { Maintain } \\
\text { standards }\end{array}$ & $\begin{array}{c}\text { Lower } \\
\text { standards }\end{array}$ \\
\hline \multirow{2}{*}{ Country B } & $\begin{array}{l}\text { Maintain } \\
\text { standards }\end{array}$ & $\begin{array}{l}\text { A. } \\
\text { Core labor } \\
\text { standards }\end{array}$ & B. \\
\hline & $\begin{array}{l}\text { Lower } \\
\text { standards }\end{array}$ & C. & $\begin{array}{l}\text { D. } \\
\text { No core } \\
\text { labor } \\
\text { standards }\end{array}$ \\
\hline
\end{tabular}

standards, the other has an incentive to lower standards and gain a competitive advantage. Consequently, both end up lowering standards. The only way to sustain the socially optimal equilibrium is to have global labor standards that bar countries from taking the low road.

Interestingly, this race to the bottom dynamic has usually been conceived in terms of competition between north (industrialized countries) and south (developing countries). However, there appears to be a growing recognition that it may operate principally between southern countries. Thus, G. Berik (2001) found in her study of the Pakistan soccer ball industry that moves to restrict the use of child labor contributed to production moving out of Pakistan to India. In this instance Pakistan tried to maintain standards, and it was then undercut competitively by India.

\section{Making Labor Standards Part of the System of Global Governance}

Labor standards are good development policy and should therefore become a core piece of the global governance structure now being constructed. The ILO will retain a critical role regarding the monitoring of country adherence to standards, and it also has special capabilities to advise governments as to how to develop systems for enforcing labor standards. However, beyond this, the international financial institutions (IFIs)-as represented by the International Monetary Fund, the World Bank, and the regional development banks-must all officially promote core labor standards as part of their mission. The articles of agreement of the IFIs require them to adopt policies that are "economically justified," and labor standards pass this critical (and appropriate) test. The IMF, the World Bank, and the multi-lateral regional development banks are all in the 
"business of development," and this is why labor standards should be part of their standard operating procedures.

With regard to the IMF, annual Article IV country reviews conducted by the IMF should explicitly report on countries' adherence to labor standards. This can help spotlight behavior as well as contribute to the emergence of a global labor market policy norm. Countries should also be obliged to meet labor standards conditions to receive enhanced structural adjustment loans (ESAFs) from the IMF. These conditions need not require that countries immediately meet labor standards, but they must at a minimum require an effective plan that will ensure compliance by a reasonable date certain. Finally, to receive IMF special drawing rights (SDRs) countries are obliged to follow IMF policy, and this policy should now be amended to require countries to commit to labor standards. Just as the IMF now requires countries to pursue policies that promote good governance, so too the IMF should require that countries commit to ILO labor standards. ${ }^{6}$

With regard to the World Bank and the regional development banks, country assistance strategies (CAS) which guide all bank lending should incorporate an explicit focus on labor standards. All loans are currently screened with regard to their environmental impact, and loans should now also be subject to a "core labor standards" assessment. Once again, countries that do not currently meet core labor standards could satisfy this assessment by putting forward a satisfactory plan that details how they will achieve compliance by a reasonable date certain.

Finally, there is also a place for core labor standards in the world trading system as administered by the World Trade Organization (WTO). The WTO should have the right to penalize countries that violate labor standards. Trade-related labor standards disputes should be administered through a dispute resolution process similar to that governing the administration of intellectual property rights, and this dispute resolution process should also have access to the same set of remedies.

\section{Conclusion}

Child labor is now widely recognized as an unacceptable scourge. Less widely understood are the policy implications that follow from recognizing that it is a problem that is rooted in labor market dysfunction and economic under-development. While voluntary corporate codes of conduct and "free of child labor" product-labeling programs have an important role to play in highlighting the problem of exploitative child labor, they fail to tackle the root causes of the problem.

Elimination of exploitative child labor requires the global adoption and enforcement of the entire body of ILO core labor standards. These standards address the root causes of child labor-namely inefficient functioning of labor markets and lack of economic development. Unfortunately, core labor standards are all too often misrepresented as a form of "imperial bullying" and "hidden protection for industrialized 
countries" when the reality is that they constitute good economic policy. Labor standards are good for developing countries because they help remedy the problem of labor market exploitation. They also contribute to deep economic development by positively impacting the distribution of income in a way that fosters robust domestic markets and by promoting institutional developments conducive to good governance. Finally, they are good for the international economy because they tilt country development away from reliance on export-led growth, which is a strategy that is inconsistent when considered at a global level. The scourge of exploitative child labor can only be eliminated by building labor markets that function for the benefit of working people and by fostering economic development. Core labor standards contribute to realizing both of these goals and for this reason are at the heart of the solution to the child labor problem.

\section{Notes}

1. Figures are from Sorgho-Ouedraogo 2001.

2. L. R. Y. Storrs $(2000,2)$ reported that the women of the National Consumer League (NCL) came to the same conclusion in their efforts to civilize capitalism in the early part of the twentieth century: "Before long, however, the NCL recognized that the strategy of using public pressure to elicit voluntary compliance by employers had serious limitations. The reformers concluded that employers would have to be coerced, rather than persuaded, into fair labor practices."

3. M. Power (1999) surveyed some of the same literature as it relates to arguments made in the early twentieth century for a living wage for women.

4. This section is drawn from Palley, Drake, and Lee 1999.

5. In Europe, a similar outcome has been achieved through the application of a "social clause" to the entire European Union.

6. The IMF Executive Board approved a guidance note titled "The Role of the IMF in Governance Issues" on July 25, 1997.

\section{References}

Altman, M. "A Revisionist View of the Economic Implications of Child Labor Regulations." The Forum for Social Economics (spring 2001): 1-23.

Atkinson, G. "Capital and Labor in the Emerging Global Economy." Journal of Economic Issues 31, no. 2 (June 1997): 385-91.

Basu, K., and P. H. Van. "The Economics of Child Labor.” American Economic Review 88 (June 1998): 412-27.

Berik, G. "What Happened after Pakistan's Soccer Ball Industry Went Child Free." Paper presented at the Conference on Child Labor held at the Graduate School of Social Work, University of Utah, Salt Lake City, Utah, May 7-8, 2001.

Clark, J. B. “The Minimum Wage." Atlantic Monthly 112 (September 1913): 289-97.

Commons, J. R. "American Shoemakers, 1648-1895: A Sketch of Industrial Evolution." Quarterly Journal of Economics 24 (November 1909): 39-84.

Elmslie, B., and W. Milberg. "Free Trade and Social Dumping: Lessons from the Regulation of U.S. Interstate Commerce." Challenge (May-June 1996): 46-50.

Groat, G. G. "Comment on Seager." American Labor Legislation Review 3 (1913): 106-9. 
Grootaert, C., and R. Kanbur. “Child Labor: An Economic Perspective.” International Labor Review 134 (1995): $187-203$.

Kelley, F. "Minimum Wage Laws." Journal of Political Economy 20 (December 1912): 999-1010.

Palley, T. I. "The Economic Case for International Labor Standards: Theory and some Evidence." 1998. Reissued as AFL-CIO Public Policy Department Economic Policy Paper E036, 1999.

—. "Labor Standards, Economic Governance, and Income Distribution: The Cross-Country Evidence." AFL-CIO Public Policy Department Technical Working Paper T029, 2000.

Palley, T. I., E. Drake, and T. Lee. "The Case for Labor Standards in the International Economy." Report Submitted to the International Financial Institution Advisory Commission of the US Congress, November 1999.

Power, M. "Parasitic-Industries Analysis and Arguments for a Living Wage for Women in the Early Twentieth-Century United States." Feminist Economics 5 (1999): 61-78.

Prasch, R. E. "American Economists and Minimum Wage Legislation during the Progressive Era: 1912-1923." Journal of the History of Economic Thought 20 (November 1998): 161-175.

_. "American Economists in the Progressive Era on the Minimum Wage." Journal of Economic Perspectives 13 (spring 1999): 221-230.

Rodrik, D. "Democracies Pay Higher Wages." Quarterly Journal of Economics 64 (August 1999): 707-38.

Sinclair, U. The Jungle. 1905. Reprint, New York: Heritage Press 1965.

Sorgho-Ouedraogo, A. "Combating Child Labor: International Support for Grass Root Action. An ILO-IPEC Operational Experience." Paper presented at the Conference on Child Labor held at the Graduate School of Social Work, University of Utah, Salt Lake City, Utah, May 7-8, 2001.

Storrs, L. R. Y. Civilizing Capitalism: The National Consumers' League, Women's Activism, and Labor Standards in the New Deal Era. Chapel Hill, N.C.: The University of North Carolina Press, 2000.

Wolman, L. "Economic Justification of the Legal Minimum Wage." American Labor Legislation Review 14 (September 1924): 226-33. 